\title{
過去12年間当教室における顎関節強直症患者22例の臨床統計的観察
}

\author{
上田茂樹・西嶋克巳・松村和良 \\ 矢尾尚武・下山一郎・永山久夫 \\ 矢部孝・武用光正・遠藤亨
}

\section{Clinico-statistical observation of ankylosis of temporomandibular joint in our clinic for past 12 years}

\author{
Shigeki Ueda - Katsumi Nishijima - Kazuyoshi Matsumura \\ Hisatake YAo - Ichirô ShImoYama = Hisao NAgAyama \\ Takashi YABE $=$ Mitsumasa BuYô $•$ Tôru Endô
}

緒言

䫇関節強直症は開口障害を若起する典型的な疾患であ り，臨床統計的観察については Kazanjian (1938) 1), 堀越 $(1952)^{2)}$, 宮川 - 川上 $(1957)^{3)}$, Topazian (1964) ${ }^{4)}$, 渡辺ら $(1967)^{5)}$, 上野ら (1969) ${ }^{6)}$ などの報告がみられ る. 今回われわれは, 昭和 40 年 7 月 1 日より炤和 52 年 6 月30日までの 12 年間に当科を訪れた顎関節強直症患者 22 例について臨床統計的観察を行い，いささかの知見を得 たので報告する.

\section{観 察 成 績}

\section{1. 年度別推移と発現頻度}

われわれが臨床統計的観察を行った12年間に，当科を 訪れた外来患者総数 43,349 名に対する顎関節強直症患者 数は22例 $(0.05 \%)$ であり，年度別推移は昭和 41 年, 43 年に 4 例と最も多く, 昭和 45 年, 48 年, 51 年には全くみ られなかった。 しかし特に年度別有意差は認められなか った（表1）.

\section{2. 年齢・性別}

年龄別では, 20 歳代が 7 例と最も多く, 次いで10歳代 6 例で, これらの年龄層で全体の13例 (59.1\%) と過半 数をしめていた。 また男女比では, 男性11例, 女性11例 とその差は全く認められなかった（表 2 ）.

岡山大学艘学部口腔外科学教空（主任：西嶋克巳教

授）

Department of Oral Surgery, Okayama University Dental School (Chief: Prof. Katsumi Nishijima) 受付日：昭和56年 4 月 9 日

\section{3. 主訴と性別}

男性は11例すべての症例が開口障害を主 訴としてお り，女性では開口障害を訴えたもの 8 例，審美障害を訴 えたもの 3 例がみられた。全体的には開口障害を訴えた るのが19例 (86.4\%) と大多数をしめていた（表 3 ).

\section{4. 原因之年齢分布}

原因は，外傷が10例（45.5\%）と最も多く，次いで炎 症, 全身疾患, 腫浧の打の打の 2 例 (9.1\%), 先天性 1 例 $(4.5 \%)$ の順であった。外傷では，20歳代が 4 例と 最も多く, 次いで30歳代, 50歳代おのおの 2 例の順であ った。 また男性では外傷が 8 例と最も多く, 女性では特 に顕著にみられる原因はなく, 外傷, 资症, 全身疾患お

表 1 年度別患者数

\begin{tabular}{|c|c|c|c|c|}
\hline \multirow{2}{*}{ 年 } & \multirow{2}{*}{ 外来患者総数 } & \multicolumn{3}{|c|}{ 顎関節強直症患者数 } \\
\hline & & 男 & 女 & 計 \\
\hline 40 ( 7 ～12月 $)$ & 1,338 & 0 & 1 & 1 \\
\hline 41 & 3,065 & 2 & 2 & 4 \\
\hline 42 & 3,091 & 1 & 0 & 1 \\
\hline 43 & 3,253 & 2 & 2 & 4 \\
\hline 44 & 3,254 & 3 & 0 & 3 \\
\hline 45 & 3,161 & 0 & 0 & 0 \\
\hline 46 & 3,414 & 1 & 1 & 2 \\
\hline 47 & 3,792 & 1 & 1 & 2 \\
\hline 48 & 3,897 & 0 & 0 & 0 \\
\hline 49 & 4,149 & 0 & 1 & 1 \\
\hline 50 & 4,710 & 1 & 1 & 2 \\
\hline 51 & 3,287 & 0 & 0 & 0 \\
\hline 52 ( $1 \sim 6$ 月 $)$ & 2,937 & 0 & 2 & 2 \\
\hline 計 & 43,349 & 11 & 11 & 22 \\
\hline
\end{tabular}


のおの 2 例, 腫瘍, 先天性おのおの 1 例であった。なお 炎症では中耳炎，智歯周囲炎が叔の打の 1 例及られ，全 身疾患では全身性笑埕障害によると考えられるもの 1 例 がみられた，腫瘍 2 例はいずれも骨腫であった（表 4 ）.

\section{5. 発現年齢}

発現年齢は 9 歳以下が 9 例 $(41.0 \%)$ と最も多く, 次 いで10歳代 5 例 $(22.7 \%) ， 20$ 歳代 3 例 $(13.6 \%$ ) の順 で，19歳までに発現したものが，14例 $(63.7 \%)$ と過半

表 2 年齡, 性別症例数

\begin{tabular}{|c|c|c|c|}
\hline 年齢 & 男 性 & 女 & 計 \\
\hline $0 \sim 9$ & 0 & 1 & 1 \\
\hline $10 \sim 19$ & 2 & 4 & 6 \\
\hline $20 \sim 29$ & 4 & 3 & 7 \\
\hline $30 \sim 39$ & 3 & 0 & 3 \\
\hline $40 \sim 49$ & 0 & 1 & 1 \\
\hline $50 \sim 59$ & 1 & 1 & 2 \\
\hline $60 \sim$ & 1 & 1 & 2 \\
\hline 計 & 11 & 11 & 22 \\
\hline
\end{tabular}

数をしめていた。な撜現時最高年龉は74歳で，最低年 齢は出生時であった（表 5 ）.

\section{6. 罹患部位}

部位別では，両側性 2 例 (9.1\%) に対し，片側性19 例 $(86.4 \%)$ と約10倍をしめ, 左右別では左側13例, 右 側 6 例で左側が約 2 倍であった（表 6 ）.

\section{7. 顔貌変化と罹患部位}

顎関節強直症患者22例のうち顔面非対称を呈したもの 10 例 $(45.4 \%)$, 対称のもの 6 例 $(27.3 \%)$, 鳥顔 4 例 (18.2\%), 顔面非対称で鳥顔を伴ったもの 2 例 (9.1\%) であった，部位別では，両側性 2 例のうち鳥顔および顔 面対称のものおの拈の 1 例で, 片侧性19例のうち顔面非 対称 10 例, 対称 4 例, 鳥顔 3 例, 顔面非対称で鳥顔を伴 ったもの 2 例であった（表 7 ）.

表 3 主訴と性別

\begin{tabular}{l|r|r|r}
\hline 性別 & 男 性 & 女 & 性 \\
\hline 主訴 & 計 \\
\hline 開口障害 & 11 & 8 & 19 \\
審美障害 & 0 & 3 & 3
\end{tabular}

表 4 原因と年秢分布

\begin{tabular}{|c|c|c|c|c|c|c|c|}
\hline 年踰 & 外賃 & 症 & 全身疾患 & 腫 & 先 天 性 & 明 & 計 \\
\hline $0 \sim 9$ & 0 & 0 & 0 & 0 & 0 & $1(1)$ & $1(1)$ \\
\hline $10 \sim 19$ & $1(1)$ & 0 & $2(2)$ & 1 (1) & 0 & $2(0)$ & $6(4)$ \\
\hline $20 \sim 29$ & $4(1)$ & 0 & 0 & $1(0)$ & $1(1)$ & $1(1)$ & $7(3)$ \\
\hline $30 \sim 39$ & $2(0)$ & 1 (1) & 0 & 0 & 0 & 0 & $3(1)$ \\
\hline $40 \sim 49$ & 0 & 1 (1) & 0 & 0 & 0 & 0 & $1(1)$ \\
\hline $50 \sim 59$ & $2(0)$ & 0 & 0 & 0 & 0 & 0 & $2(0)$ \\
\hline $60 \sim$ & $1(0)$ & 0 & 0 & 0 & 0 & $1(1)$ & $2(1)$ \\
\hline 計 & $10(2)$ & $2(2)$ & $2(2)$ & $2(1)$ & 1 (1) & $5(3)$ & 22 (11) \\
\hline
\end{tabular}

（）：女性

表 5 発現年龄

\begin{tabular}{r|c}
\hline 年 $\quad$ 踰 & 症 例 数 \\
\hline $0 \sim 9$ & 9 \\
$10 \sim 19$ & 5 \\
$20 \sim 29$ & 3 \\
$30 \sim 39$ & 0 \\
$40 \sim 49$ & 1 \\
$50 \sim 59$ & 2 \\
$60 \sim$ & 2 \\
\hline
\end{tabular}

表 6 羅㭧部位

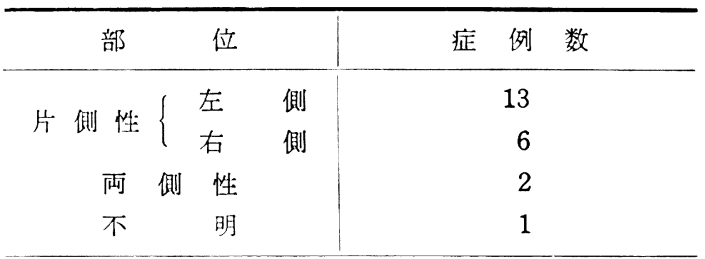


表 7 顔貌変化と部位

\begin{tabular}{|c|c|c|c|c|}
\hline 顔貌 & 両側性 & 片側性 & 不 明 & 計 \\
\hline 顔面非対称 & 0 & 10 & 0 & 10 \\
\hline 称 & 1 & 4 & 1 & 6 \\
\hline 鳥 & 1 & 3 & 0 & 4 \\
\hline 顔面非対称＋鳥顔 & 0 & 2 & 0 & 2 \\
\hline 計 & 2 & 19 & 1 & 22 \\
\hline
\end{tabular}

表 9 原因と羅患部位

\begin{tabular}{|c|c|c|c|c|c|}
\hline 部位 & & & 性 & & \\
\hline 原因 & & 右 & 左 & & \\
\hline 外 傷 & 2 & 3 & 4 & & \\
\hline 资症 & 0 & 0 & 2 & & \\
\hline 全身疾患 & 0 & 1 & 1 & & \\
\hline 尰瘍 & 0 & 1 & 1 & & \\
\hline 先 天 性 & 0 & 0 & 1 & & \\
\hline 不 明 & 0 & 1 & 4 & & \\
\hline 計 & 2 & 6 & 13 & & \\
\hline
\end{tabular}

\section{8. 発現年齢と顔貌変化}

顔面非対称を呈した10例のうち発現年龄が10歳代が 4 例と最も多く, 続いて 9 歳以下 3 例の順となっており, 19歳までに発現したものが10例中 7 例 (70.0\%) と大部 分をしめていた．顔面対称を呈した 6 例のらち，発現年 苓が40歳以上が 4 例，10歳代，20歳代が各 1 例で，20歳 以上のものが 5 例 (83.3\%) と大多数をしめていた。 ま た鳥顔を呈したもの 4 例すべてが 9 歳までに発現してい た. 顔面非対称で鳥顔を伴ったものは発現年龄が 9 歳以 下が 2 例であった（表 8).

\section{9. 原因と䍜患部位}

外傷10例のうち両側性 2 例, 不明 1 例をみるほかは, その他の原因によるものはすべて一側性であった（表 9).

\section{0. 処置前後の開口差}

処置としては，22例中観血的処置（顎関節授動術）を 行ったもの18例, 非観血的処置を行ったもの 4 例であっ た. 観血的処胃（顎関節授動術）を行ったものでは，処 直前後の開口差が 15〜19 mm のもの 6 例 (33.3\%) と 最も多く, 次いで 10〜 $14 \mathrm{~mm}$ のものが 5 例 (27.8\%), $5 \sim 9 \mathrm{~mm}, 20 \sim 24 \mathrm{~mm}$ のものがおのおの 2 例 (11.1 \%) の順であった。 なお開口差の最高は $30 \mathrm{~mm}$ で最低 は $3 \mathrm{~mm}$ であった，次に非観血的処置を行ったもので は, 開口差 $20 \sim 24 \mathrm{~mm}$ のもの 1 例を除く他の 3 例は, すべて $4 \mathrm{~mm}$ 以下でほとんど開口状態は改善されてい
表 8 発現年龄と顔貌変化

\begin{tabular}{|c|c|c|c|c|c|c|}
\hline 年齢 & $\begin{array}{l}\text { 顔面非 } \\
\text { 対称 }\end{array}$ & 顔面対称 & 鳥 & 顔 & $\begin{array}{l}\text { 顔面非対 } \\
\text { 称十鳥顔 }\end{array}$ & 計 \\
\hline $0 \sim 9$ & 3 & 0 & 4 & 4 & 2 & 9 \\
\hline $10 \sim 19$ & 4 & 1 & 0 & 0 & 0 & 5 \\
\hline $20 \sim 29$ & 2 & 1 & 0 & 0 & 0 & 3 \\
\hline $30 \sim 39$ & 0 & 0 & 0 & & 0 & 0 \\
\hline $40 \sim 49$ & 0 & 1 & 0 & & 0 & 1 \\
\hline $50 \sim 59$ & 1 & 1 & 0 & & 0 & 2 \\
\hline $60 \sim$ & 0 & 2 & 0 & & 0 & 2 \\
\hline 計 & 10 & 6 & 4 & & 2 & 22 \\
\hline
\end{tabular}

表 10 処置前後の開口差

\begin{tabular}{|c|c|c|}
\hline $\begin{array}{l}\text { 上下顎中切 } \\
\text { 雬間 (mm) }\end{array}$ & 観血的処置 & 非観血的処置 \\
\hline$\sim 4$ & 1 & 3 \\
\hline $5 \sim 9$ & 2 & 0 \\
\hline $10 \sim 14$ & 5 & 0 \\
\hline $15 \sim 19$ & 6 & 0 \\
\hline $20 \sim 24$ & 2 & 1 \\
\hline $25 \sim 29$ & 1 & 0 \\
\hline $30 \sim$ & 1 & 0 \\
\hline 計 & 18 & 4 \\
\hline
\end{tabular}

表 11 顎関節強直症の種類と発現年龄

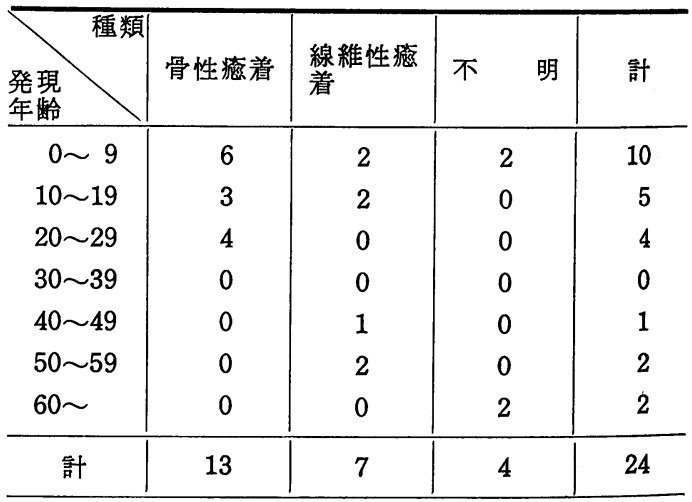

なかった（表 10）。

\section{1. 顎関節強直症の種類と発現年齢}

両側性の 2 例を加えて 24 䫛関節中, 骨性瘑着 13 例 $(54.2 \%)$ ，線維性瘑着 7 例 (29.2\%)，不明 4 例 (16.6 \%) で, 骨性痛着が線維性癒着の約 2 倍をしめていた. また発現年齢との関係では, 骨性瘉着13例中最も多かっ たのが, 9 歳以下 6 例 (25.0\%), 次いで20歳代 4 例(16.7 
$\%), 10$ 歳代 3 例 (12.5\%) で, 30 歳以上には全くみら れず，比較的若年に発現した場合が多かった。また線維 性癒着の場合は, 9 歳以下, 10 歳代, 50 歳代がおのおの 2 例, 40 歳代 1 例で, 特に有意差は認められなかった (表11).

\section{考}

\section{察}

昭和 40 年 7 月 1 日より昭和 52 年 6 月 30 日までの 12 年間 に当科を訪れた靧関節強直症患者 22 例について，年度別 有意差は特に認められなかった。 また発現頻度は，外来 患者総数 43,349 名に対して約 2,000 人に 1 人とい5割合 であった。

靧関節強直症の性別頻度について宮川 = 川上 $(1957)^{33}$ は女性32例, 男性22例, 藤岡ら (1968) ${ }^{7)}$ は女性 6 例に 対し男性 1 例と女性が男性に比べ多かったと報告し, 渡 辺ら (1967) ${ }^{5)}$ は14:13, 上野ら (1969) ${ }^{6)}$ は87:89 と性 別差はあまりみられなかったと報告している。われわれ の統計でも男性11例, 女性11例と性別差は認められなか った。

受診時の年齢について Orlow $(1903)^{8)}$, Topazian $(1964)^{4)}$, 渡辺 $5^{5)}$, 藤岡 $ら^{7)}$ は, 10, 20歳代にかけて多 くみられたと述べているが，われわれの統計でも10，20 歳代で全体のうち13例 (59.1\%) をしめ, 同様の結果が 得られた。

主訴別では開口障害19例, 審美障害 3 例とみられ，開 口障害が圧倒的に多かった。審美障害の 3 例すべてが女 性であったことが注目された。

原因別では Orlow ${ }^{8)}$, Kazanjian (1938) 1), 堀越 $(1952)^{2)}$, 宮川・川上 ${ }^{3)}$, 渡辺ら5)は炎症によるものが最 む多く次いで外傷であり, 全身疾患, 先天性のものは比 較的稀であったと述へ，また上野ら ${ }^{6)}$ は外傷が最も多 く，次いで炎症であったと報告している．われわれの統 計では外傷が10例之最も多く, 炎症, 全身疾患, 畽瘍, 先天性はおのおの 2 例と比較的少なかった，原因が炎症 のものには, 中耳炎 ${ }^{9)}$, 下顎骨炎・乳突起炎 ${ }^{7)}$, 耳下腺 炎3)などが報告されている。 また全身疾患によるもの 2 例がみられたが，そのうち1例は熱性疾患によるもので

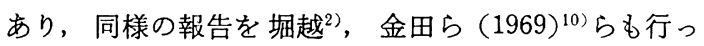
ている。 また岡 $(1959)^{11)}$ は淋病, 腸チフス, 肺炎, 猩 紅熱，結核などが血行感染をきたし，化膿性関節炎を招 来することがあると述べている，外傷に関して Risdon $(1934)^{12)}$, Thoma (1952) ${ }^{13)}$ は関節突起の骨折を举げ, この部位の骨折は発見されにくく従って放置された場 合, 顎関節強直症の原因になりやすいと述べている。 た今上 $(1977)^{14)}$ は顎骨骨折の 治療として罘間固定を行 らが，長期にわたる関節の非動化により顔関節強直症を 生じたと実験的研究を報告している．したがって䫈間固 定の期間は, 顎関節強直症起因といら点から十分考虙す
る必要があるように思われる。先天性については宮川・ 川上 ${ }^{3)}$, 渡辺 $5^{5)}$, 金田 ${ }^{(0)}$ らの報告が 及られるが, Dingman (1948) $\left.{ }^{15}\right)$ は真の先天性のものは理論的にはあ りらるが，その頻度はまれで，実際には鉗子分婏などの 出生時の外傷によるものも含まれると述べている。また Thoma ${ }^{13)}$ は, これを Birth injury と表現している.わ れわれの統計において，腫瘍によるものが 2 例みられた が, 当教室の西嶋ら $(1972)^{16)},(1974)^{17)}$ がその詳細を 報告している。 また Shackelford and Brown(1943) ${ }^{18)}$, $(1949)^{19)}$, Brailsford $(1952)^{20)}$ が骨軟骨腫による開口障 害の例を報告している。

発現年蹂についてわれわれの統計では 9 歳以下が 9 例 と全体の約 40\%をしめていたが，Kazanjian'1)，渡辺ら $(1963)^{21)}$ らも10歳未満が多くみられたと述べている。 こ のことについて藤岡らりは, 幼児期には中耳炎, 下顎骨 炎，打撲などが多いためであるらと述べている。

罹患部位別では Kazanjian ${ }^{1}$ は28例中24例, Thom $x^{13}$ は21例中15例, 上野 ${ }^{6)}$ は 113 例中87例が片側性で両側 性に比べ多かったと述べている，われわれの統計におい ても同様に片側性19例 (86.4\%) と圧倒的に多かった。 また片側性の左右別では, 左側が右側の約 2 倍をしめて いたが，宮川・川上 ${ }^{3)}$ は右側 21 例, 左側 27 例, 渡辺ら5) は右側 4 例, 左側 9 例之左側, 上野ら ${ }^{6)}$ は右側58例, 左 側29例々右側が多くみられたと述べている。

顔貌の変化と罹患部位について Dagher and McDonald $(1957)^{22)}$, 渡辺 ${ }^{21)}$ は, 靧骨の発育途中に䋶関節 強直症が発症した場合下顎の 発育成長が著しく抑制さ れ, 両側性の場合は鳥顔を呈し, 片側性の多くは健側の 成長が大体正常に行われるため, 患側に偏位して非対称 の顔貌にやりやすいと述べている。われわれの統計で は, 顔面非対称のものはすべて片側性であったが, 片側 性のものにも鳥顔を呈した例がみられた。

発現年齢と顔貌の变化について Dagher and McDonald ${ }^{22)}$ は, 顎の成長が完成する14歳以後に頸関節強 直症が生じた場合, 顔貌の変化は少ないと述べている。 われわれの統計においても19歳以下の14例中対称のもの は1例しかなく, 大多数は非対称ないしは鳥顔を呈して いた.これに対し20歳以上の場合は, 8 例中 5 例と半数 以上の顔貌が対称性であった。

原因と罹患部位について渡辺 $5^{5)}$ は外傷, 全身疾患は 両側性, 片側性の両方ともみられたが, 局所の炎症は片 側性のみであったと報告しており，また風(1959)"1)は局 所性炎症の場合は片側性に多く,リューマチ, 系統的血 行感染, 介達性外傷は両側性に多くみられたと述べてい る.われわれの統計において, 外傷では両側, 片側性の 両方がみられたが，その他の原因に执いては片側性のみ がみられた。

腼関節強直症の処置について岡 ${ }^{11}$ は, きわめて初期の 線維性癒着の場合, 非観血的暴力矯正, 関節離断術が行 
われることもあるが，再発や増悪をきたすことが多いの で現在ではほとんと行われていないと述べている。した がって現在では観血的に䫟関節授動術が行われている が，われわれの統計においても22例中 4 例では全身状態 が悪いなどの理由で，開口練習などの非観血的処咱のみ を行ったが，そのほとんどが全く症状の改善をみなかっ た.しかし顎関節授動術を行った 18 例では，平均約 16

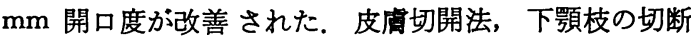
部位について従来より種々の報告がなされてきた。皮 覻切開法には Kocher, Payr, Konig らの耳前切開法と Bockenheimer-Axhausen の耳後切開法に大別される. 前者は手術部位に容易に達しらるといら利点と顔面神経 域を損傷しやすく，また瘢痕が目立ちやすいという久点 があり，後者は神経血管の損傷を予防でき，審美的にも 優れているが，上野 $(1960)^{23)}$ によると創孔に制限があ り，広汎な骨性癒着の場合には手術が困難であると述べ ている，金田ら ${ }^{10)}$ は癒着が広範囲に及んだ症例や，再発 を繰返した症例について瘉着部に侵襲を加えることなし に，下顎枝に偽関節 を形成する Risdon 法が適応する と述べている.われわれの教室に扎いては，上野の耳前

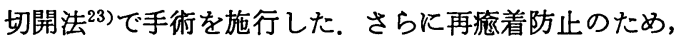
中間挿入物として腹部遊離皮膚弁を用いた。堀越2)は炎 症性疾患に由来する顎関節強直症の場合は, 中間挿入物 として皮店弁を用いると予後不良の傾向がみられたと述 べている.中間扦入物には生筋膜 ${ }^{12)}$, 合成樹脂 ${ }^{24,25)}$, 金

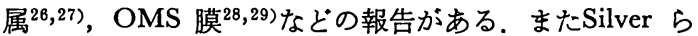
$(1977)^{30)}$, Kummoona (1978) $\left.{ }^{31}\right)$ はとれぞれバイタリウ ム，クロムコバルトを用いて作製した金属性の人工物を 関節突起に置き変え良好な結果を得たと報告している。 後処置としては, 術後よりコルク栓, 開口器を用いて 開口練習を行わせた。 術後の開口練習には，種々の装 直 ${ }^{32}{ }^{33)}$ による方法が考案されているが, 再疮着防止, 顎 運動機能回復といら点で重要であり, 術後の経過を左右 するといっても過言ではないと思ら。渡辺”はまずュル ク栓を 2 〜 週間使用させた後, 開口器を半年から 1 年 間使用させると良いと述べ，Robinson ら(1977) ${ }^{34)}$ は 術後の再瘉着を防止するためコバルト照射を行い好結果 を得たと報告している。

顎関節強直症の種類と発現年龄について清水 $(1972)^{35)}$ は，関節部の澸着は初期には線維性で多くの場合片側性 であり，長期にわたる運動制限の結果，反対側にも線維 性疮着を生じ，一方初発側では線維化の上に石灰化が起 こり骨性瘉着が生じていき，低年龄に発症したものほど 骨性癒着が多いと述べている。かれわれの統計において も，発現年龄の低い程骨性痋着が多くみられた。 また上 野 ${ }^{6)}$, Padgett ら (1948) ${ }^{36)}$, Topazian (1964) $\left.{ }^{4}\right)$ は, 骨性疮着が線維性病着に比べ多いと報告しているが，わ れわれの統計においても骨性瘉着13例に対し線維性瘉着 7 例と骨性症着が多くみられた。

\section{結}

\section{論}

岡山大学医学部口腔外科学教室を過去12年間に訪れた 顎関節強直症22例について, 種々の点から臨床統計的観 察を行い以下の結論を得た。

1. 外来患者総 数に 対する 顎関 節強 直症 患者数比は $0.05 \%$ で, 年度別推移については, 特に有意差は認めな かった。

2. 年龄別では, 20 歳代が 7 例と最も多く，男女比て は男性11例，女性11例と全く差が認められなかった。

3. 主訴別では, 開口障害を訴えたものが 19 例 (86.4 \%) と大多数をしめていた.

4. 原因別では，外傷が 10 例 (45.5\%) と最す多く, 次いで炎症, 全身疾患, 腫瘍おのおの 2 例 (9.1\%), 先 天性 1 例 $(4.5 \%)$ の順であった。

5. 発現年龄では， 9 歳以下が 9 例 $(41.0 \%)$ と最す 多かった。

6. 部位別では, 両側 性 2 例 (9.1\%), 片側性 19 例 (86.4\%) で左側13例，右側 6 例であった。

7. 顔貌変化と罹患部位については，顔面非対称を呈 したものはすべて片側性で，鳥顔を呈したものは片側 性, 両側性のいずれにす認められた。

8. 発現年齢と顔貌変化については, 19 歳以下で発現 したものは, 大多数が非対称または鳥顔を呈しており, 20歳以上では大多数が顔貌に変化はみられなかった。

9. 原因と罹患部位との関係では，両側性のすのは外 傷による 2 例で，他の20例は片側性であった。

10. 処置前後の開口差に関しては, 非観血的処置を行 った症例ではそのほとんどが開口状態は改善されておら ず，顎関節授動術を行ったものでは 平均約 $16 \mathrm{~mm}$ 改善 された。

11. 靧関節強直症の種類と発現年龄については，9歳 以下の若年齡に発現したものは, 骨性癒着が多くをしめ ていた。一方30歳以上に発現したものはすべて線維性寃 着であった。

なお，本論文の要旨は，昭和 54 年 10 月 5 日第 24 回日本 口腔外科学会総会にて発表した。

\section{引用 文 献}

1) Kazanjian, V.H.: Ankylosis of the temporomandibular joint. Surg Gynecol Obstet 67: 3331938.

2）堀越達郎：筊関節授動術の臨床的統計的観察。 口科誌 1：275 1952 .

3）宮川喜光, 川上英世 : 靧関節強直症の臨床的統 計的観察 (抄). 口科誌 6:331 1957.

4) Topazian, R.G.: Etiology of ankylosis of tem- 
poromandibular joint: analysis of 44 cases. J Oral Surg Anesth Hosp D Serv 22: 2271964.

5) 渡辺義男, 他：わが教空における過去 10 年間に 経験せる腼関節強直症27例の臨床統計的睍察。 口科誌 16: 11967.

6）上野 正, 他: 買関節強直症の療法と成續に関 する研究 (抄)。口科誌 18：246 1969 .

7）藤岡幸雄，他：最近に経臨した䫇関節強直症の 7 症例。口科誌 17: 1841968.

8) Orlow, L.W.: Ankylosis mandibulae vera. Dtsch Ztschr f Chir 66: 3991903.

9）渡边 ：顎関節強直症と其の手術的療法。日 本医事新報 1001：3 1941 .

10）金田敏郎，他：顎関節強直症に対する下顎枝低 位関節形成術。口科誌 18:804 1969.

11）岡達: 顎関節の疾患 (4). 㐘界展望 16 : 1641959.

12) Risdon, F.: Ankylosis of the temporomaxillary joint. J Am Dent Assoc 21: 19331934.

13) Thoma, K.H.: Oral Surgery II . ed 2, Mosby Co, St Louis, 1952, p 880.

14）今上茂樹：顎関節損伤後の機能回復と組織修復 過程に顎運動が及ぼす影貔に関する実験的研究. 口科誌 26: 4311977.

15) Dingman, R.O.: Ankylosis of the temporomandibular joint. Am J Orthodont 32: 120 1948.

16）西嶋克巳，他：左側下顎骨筋突起の外骨腫に由 来した開口障害の 1 例. 日口外誌 18：59 1972.

17）西嶋克巳，他：右側顎関節部に発生した骨腫の 1 例。日口外誌 20：365 1974 .

18) Shackelford, R.T. and Brown, W.H.: Osteochondroma of the coronoid process of the mandible. Surg Gynecol Obstet 77: 511943.

19) Shackelford, R.T. and Brown, W.H.: Restricted jaw motion due to osteochondroma of the coronoid process. J Bone Joint Surg 31A: 107: 1141949.

20) Brailsford, J.F.: An unusual osteochondroma from the coronoid process of the mandible. $\mathrm{Br}$ J Radiol 25: 5551952.

21）渡辺義男, 他：左側下顎枝離断扎よび骨移植に
上万顔面非対称を伴 5 小下買症の 1 治験例。形 成外科 4: 2241963.

22) Dagher, I.K. and McDonald, J.J.: Ankylosis of the temporomandibular joint. Oral Surg 10: 11451957.

23）上野 正：罰関節授動手術の耳前皮庵切開法に ついて. 口外誌 6:206 1960.

24）大西正俊，他：関節鏡を診断に応用した顎関節 強直症の治験例。日口外誌 22: 31976.

25）副島公生，他：顎関節強直症の 2 症例。日曾評 論 327: 591970.

26) Eggers, G.W.N.: Arthroplasty of the temporomandibular joint in children with interposition of tantalum foil. J Bone Joint Surg 28: 6031946.

27）增田種男，石田勝一：䫇関節授動術に於ける中 間扱入物としてコバルト・クローム合金使用の 長期観察。口科誌 6：451 1957 .

28）奥田義正，松野誠夫：OMS 膜扦入に上る関節 形成術の臨床。外科 12:390 1950 .

29）藤野博, 他: 顎関節強直症の手彷. 形成外科 6: 2111963.

30) Silver, C.M., et al.: Arthroplasty of the temporomandibular joint with use of avittallium condyleprothesis: report of three cases. J Oral Surg 35: 9091977.

31) Kummoona, R.: Functional rehabilitation of ankylosed temporomandibular joint. Oral Surg 46: 4951978.

32) 田代英雄, 他: 送気式開口器の試作. 形成外科 7: 1461964.

33) Kaban, L.B., et al.: Postoperative physiotherapy device of mandibular hypomobility. Oral Surg 43: 5131977.

34) Robinson, M., et al.: Cobaltradiation to prevent reankylosis after repeated surgical failures: report of case. J Oral Surg 35: 850 1977.

35）清水正䏤：買関節強直症とその治療。歯界広報 30: 11972 .

36) Padgett, E.C., et al.: Ankylosis of the temporomandibular joint. Surg 24: 4261948. 